\title{
Institutional Adjustment Planning for Full Employment
}

\section{Fadhel Kaboub}

The idea of government as the Employer of Last Resort (ELR) has been present in the Institutionalist literature since the early twentieth century. In 1919, well before Keynes recognized that capitalist economies lack an inherent mechanism to create full employment, John Dewey wrote:

The first great demand of a better social order, I should say, then, is the guarantee of the right, to every individual who is capable of it, to work - not the mere legal right which is enforceable so that the individual will always have the opportunity to engage in some form of useful activity, and if the ordinary economic machinery breaks down through a crisis of some sort, then it is the duty of the state to come to the rescue and see that individuals have something to do that is worth while - not breaking stones in a stoneyard, or something else to get a soup ticket with, but some kind of productive work which a self-respecting person may engage in with interest and with more than mere pecuniary profit. Whatever may be said about the fortune of what has technically been called socialism, it would seem to be simply part of ordinary common sense that society should reorganize itself to make sure that individuals can make a living and be kept going, not by charity, but by having productive work to do. ([1919] 1939, 420-421)

Several prominent institutionalists such as Morris Copeland (1967), Wendell Gordon (1980; 1997), and Hyman Minsky (1986) have strongly expressed their support to an ELR policy to deal with persistent unemployment. This paper argues that Fagg Foster's theory of Institutional Adjustment (IA) provides an

The author is an Assistant Professor in the Department of Economics at Drew University. This paper was prepared for presentation at the ASSA/AFEE conference in Chicago, January 2007. 
insightful contribution to the way in which ELR might be introduced to ensure successful implementation. Foster argued that ". . . all answers to all real economic problems necessarily take the form of institutional adjustment" (Foster 1981a, 946). Therefore, ELR too should be viewed as a process of institutional adjustment. This paper demonstrates that ELR with IA planning addresses many of the challenges that ELR critics predict. Consequently, it provides a brief overview of the ELR program and Foster's theory of IA, followed by an assessment of how IA planning can help ELR deal with structural and technological unemployment problems, and closes with concluding remarks.

\section{ELR Explained}

Contemporary ELR policy, a la Hyman Minsky, proposes that the government ought to create "an infinitely elastic demand for labor at a floor or minimum wage that does not depend upon long-and short-run business profit expectations. Since only the government can divorce the offering of employment from the profitability of hiring workers, the infinitely elastic demand for labor must be created by government" (Minsky 1986, 308). As such, the government guarantees a real job opportunity for anyone ready, willing, and able to work at a fixed socially-established basic wage (plus benefits), thus exogenously setting the price of labor. With ELR, the government will provide a price anchor and establish greater price stability. During a recession, the size of the ELR pool increases to absorb workers displaced from the private sector, and when the economy booms it automatically shrinks when ELR workers find employment in the private sector, hence it operates as a buffer stock employment program. The ELR wage is fixed while the quantity of labor in the buffer stock fluctuates. Private sector employers can obtain labor at a mark-up over the ELR fixed wage; hence, the price-stabilization feature of the program. ELR is a decentralized program, to be financed by the national government, and is not meant to substitute for private sector (nor public sector) jobs but rather complements "the market" by acting as a buffer stock for labor (Wray 1998a; 1998b; 1999).

Building on Abba Lerner's functional finance theory, ELR proponents argue that the government always has the financial capacity to pay for the program. Unemployment only develops "because government spending is insufficient relative to private savings" (Mitchell 2001, 23). The size of the deficit necessary to maintain full employment is irrelevant; and so is the national debt for the simple reason that the logic of government finances is totally different from that of households or firms. ELR proponents show that tax payments do not and cannot finance government spending; for at the aggregate level, only the government can be the "net" supplier of fiat money. As a result, the starting point is government expenditure. Once government spends (creates or supplies) fiat money to purchase goods and services, it provides the private sector with the necessary amount of money to meet tax liabilities, save, and maintain transaction balances. The government can safely run a deficit up to the point where it has provided the quantity of non-interest-earning fiat money and 
interest-earning bonds desired by the public (Wray 1998a; Mitchell 2001; Bell 2000; 2001). Several cost estimates indicate that ELR spending can be as little as $1 \%$ of GDP in the case of the United States, 3.5\% in Australia, and less than 5\% of GDP in the case of a developing country like Tunisia (Mitchell and Watts 1997; Gordon 1997; Kitson, Michie and Sutherland 1997; Majewski 2004; Fullwiler 2005; Kaboub 2006).

\section{Institutional Adjustment and Economic Policy}

Social problems (such as unemployment), emerge when the existing institutional structure does not support the life processes of the community. Addressing social problems entails policy formulation and policy implementation. Answering, and solving a social problem such as unemployment requires an economic policy response which in turn entails institutional adjustment. Institutional adjustment is a process based on three principles: technological determination, recognized interdependence, and minimal dislocation (Foster 1981b).

\section{Technological Determination}

According to Foster (1981b), the basic data of social problems is technology - the present state of the arts. In Institutional economics, the concept of technology is extended to include not only tools, machinery, and techniques of production, but also technology as a process arising from the human proclivity for workmanship and idle curiosity, as described by Veblen. Technology includes the prevalent habits of thought associated with a given state of the arts and sciences. The industrial structure, trade arrangements, monetary system, exchange rate regimes, and economic theory are all part of the technological determination of economic problems. ELR is therefore to be looked at as policy of technological change.

Problem-solving involves the utilization of the existing technological base. In a cumulative causation manner any new technological setting is a variation of the predating state of the arts and an expression of a developmental continuity. Thus, all institutional adjustment is grounded in the existing processes, tools, and habits of thought. Addressing economic problems such as unemployment through an ELR policy cannot avoid incorporating the preexisting habits of thought.

How then does change occur? Institutional adjustment is rooted in technological determination, but not in technological determinism, since human agency is essential in this process. The emergence of novelty is a result of human agency expressed through variation in instrumental valuation. The institutional theory of technological dynamic is conceptually linked to the theory of instrumental valuation (Bush 1988, 140). The result of an institutional adjustment creates new possibilities for idle curiosity and problem solving; and at the same time constitutes the data for new social problems.

ELR policy will be accompanied by a process of institutional adjustment that will bring about solutions to the problem at hand, but also some unintended 
consequences that will bring about new social problems. It is therefore crucial for ELR policy-makers to simulate the institutional adjustment process that will take place with the implementation of ELR. Such simulation can only be useful if the policymakers carefully identify the preexisting institutional structure and determine how it will be transformed/disturbed/changed by ELR. The criteria for valuation of what is instrumentally efficient and thus for selecting among alternative institutional arrangements also vary. In Institutional economics, a major criterion for instrumental valuation is the continuity of human life (Swaney 1988; Tool 1993). ELR policy must therefore ensure the continuity of the life process in order to be instrumentally efficient.

\section{Minimal Dislocation}

The principle of minimal dislocation addresses the question of what can be done with the existing institutional arrangements and discloses the limits of adjustment, which must utilize most of the existing technological data. This principle provides insight into the problems that must be addressed in policy formulation. How can an ELR policy be introduced in a manner that engenders minimal dislocation within the existing institutional social fabric? Factors such as industrial structure, labor force qualifications, socio-political institutions, and environmental concerns - as well as the existing governmental and non-governmental institutions that are already trying to remedy the unemployment problem - must be taken into account by ELR policymakers, and in fact, should be used and then gradually modified to act as a springboard for a full-fledged ELR program. This will guarantee minimal dislocation and a smooth institutional adjustment process that does not disturb the continuity of the life process. Technological change always involves dislocation in the institutional structure because the displaced institutions are interlinked with other institutions throughout the social structure. An ELR policy will indeed affect (and will be affected by) the industrial structure, labor force qualifications, socio-political institutions, and environmental concerns - as well as the existing governmental and non-governmental institutions - that are very specific to each country. Therefore, ELR with IA is the antithesis of shock therapy ELR.

\section{Recognized Interdependence}

The new standards of instrumental valuation need to become known to the community at large (government and non-government, corporate, labor, unemployed, and media organizations). There must be a mechanism that facilitates the capacity for social understanding of the necessity of institutional adjustment - public education, the media, workplace, economic education etc. (although these public spaces can also inhibit the process of institutional adjustment). As a consequence, the community's recognition of the necessity of life-sustaining, life-enhancing availability of employment is essential for the implementation of ELR. A distinction among workfare, welfare, and true full employment policy in the mind of the community is also an example of a recognized interdependence as a key component of successful 
institutional adjustment. Recognizing the fallacy of composition in approaching a macroeconomic problem of unemployment by addressing its microeconomic symptoms is another example of recognized interdependence. Job search-promoting policies and policies that promote worker mobility cannot deal with the unemployment problem if it is arising from low effective demand. Yet, there needs to be recognition that even if the effective demand problem could be rectified by government expenditures, changes in techniques of production and in the composition of final demand impose intersectoral shifts in employment - a process of IA. Finally, IA may be inhibited by the difficulty to identify and recognize the interdependence between various institutions. Failure to do so is often the main obstacle to problem solving.

\section{Coevolutionary Sustainability}

Extending Foster's principles of IA, James Swaney (1988) introduced the principle of coevolutionary sustainability referring to the compatibility of sociosystem with ecosystem while answering particular social problems. The impact of the social system on biospheric change, and the application of institutional arrangements on the evolving biosphere are part of the social problems and IA. For instance, many of the ELR jobs in developing countries will be created through public works projects that entail environmental cleanup, seashore cleanup, anti-deforestation, anti-desertification (dune fixation), anti-salinization, flood control, storage of runoff waters, creation/ expansions of public parks, recycling projects, construction and maintenance of smallscale irrigation systems, soil conservation, small-dam construction, watersheds protection from erosion, management of renewable resources such as forests and groundwater supplies, conservation of common pasture lands, land terracing, land consolidation, construction of bio-gas plants, and installation of solar energy packages. All of these ELR projects would be consistent with the principle of coevolutionary sustainability; they would reduce unemployment and at the same time enhance the condition of the ecosystem. Other traditional public works projects, however, might create more strain on the ecosystem while at the same time reducing unemployment. It is therefore imperative to design an ELR program that embraces a balanced set of life-sustaining, life-enhancing projects, both at the sociosystem as well as the ecosystem level.

The principle of coevolutionary sustainability complements technological determination by including environmental issues as part of social problems and IA. It complements the principle of minimal dislocation since it allows for recognizing that answers to social problems may impact ecosystems with the effect of creating additional social problems and the necessity for further IA. Finally, coevolutionary sustainability extends the principle of recognized interdependence by underlining the necessity of perceiving human lives as parts of ecosystems. A successful ELR plan must, therefore, be consistent with the basic principles of IA outlined above. We have thus far established the necessity of planning for IA before implementing ELR, now we will consider how such planning can help ELR face the structural and technological unemployment challenges. 


\section{ELR with Structural and Technological Change}

ELR critics (Sawyer 2003; 2005; Kadmos and O'Hara 2000) have expressed concerns about ELR's capability to deal with structural unemployment. Even though these concerns have been addressed by Forstater $(1998 ; 1999 ; 2002)$, it is important to highlight the contribution of Foster's theory of IA in helping to resolve structural and technological change problems. Structural and technological change (STC) is a constant feature of capitalist economies. Currently, however, governments do not have any systematic way of dealing with STC. At best, they react to STC after it has happened and after workers have been displaced, only then does retraining begin and the search for solutions undertaken. Governments only deal with the problem after it has made an appearance on the surface instead of dealing with its root causes. This is a very inefficient and irresponsible way of dealing with STC.

An ELR program with careful IA planning must incorporate an STC research division that works closely with business and union leaders, as well as technical training experts, in order to constantly study the structural changes in the economy. This allows ELR to stand ready to provide technical training for displaced workers so that they can reintegrate the labor force in the most effective way. The STC unit must function under an institutional adjustment philosophy that recognizes interdependence, technological determination, minimal dislocation, and coevolutionary sustainability as basic requirements for the continuation of the life process.

ELR's STC unit can provide a preemptive and systematic preventive program to minimize the damage caused by STC. STC is an institutional problem; therefore the solution for it must be institutionalized as well. The STC unit will have a watch list of at-risk industries and at-risk regions so that the ELR administration can stand ready to provide ELR jobs and retraining programs in the areas affected and for the skills needed. Laws can also be introduced to make it mandatory for at-risk industries to alert ELR authorities of imminent closures so that ELR jobs can be planned accordingly.

ELR critics (Sawyer 2003; 2005) have also questioned the capability of ELR to immediately provide jobs to displaced workers. Once again, this can be secured with careful planning. ELR authorities must create a reserve shelf of ELR projects. ELR administrators will have to be proactive and plan ahead for the business cycle (use forecasting techniques, follow leading and lagging indicators) in order to avoid delays in the initiation of ELR projects, but most importantly to avoid sudden project cancellations due to improvement in private sector activity. Once ELR is up and running, business cycle swings will become milder, hence it will be easier for ELR administrators to forecast cycles and to plan ahead. ELR critics tend to ignore the positive "expectations" effect of ELR, which will have a stabilizing effect on investment, consumption, and economic growth. Once again, ELR must be phased in progressively to allow for institutional adjustment (not a shock therapy ELR). 


\section{Conclusion}

Historically, Institutionalists have endorsed the ELR program as a matter of principal for the sake of social justice, but very little has been done to incorporate the basic principles of institutional adjustment into ELR planning. Therefore, the contribution of this paper is in proposing Foster's theory of IA as a powerful tool for ELR policymakers to ensure that the planning and implementation of full employment are consistent with the principles of technological determination, recognized interdependence, minimal dislocation, and coevolutionary sustainability. The conclusion is that a robust ELR-IA planning mix can help ELR deal with unemployment problems stemming from structural and technological change. An STC research unit inspired by the basic principles of IA can serve as the signaling device for structural unemployment and allows the ELR administration to plan for STC-related unemployment in a timely manner. Shock therapy ELR may be able to solve unemployment problems in the short run, but continuous full employment can only be ensured through institutional adjustment planning.

\section{References}

Bell, Stephanie. “Do Taxes and Bonds Finance Government Spending?" Journal of Economic Issues 34, 3 (2000): 603-620.

"The Role of the State and the Hierarchy of Money," Cambridge Journal of Economics 25 (May 2001): 149-163.

Bush, Paul. "The Theory of Institutional Change." In Evolutionary Economics: Foundations of Institutional Thought, Vol. I, edited by Mark Tool. Armonk, NY and London, England: M. E. Sharpe, 1988.

Copeland, Morris A. "Implementing the Objective of Full Employment in Our Free Enterprise Economy." In Institutional Adjustment: A Challenge to a Changing Economy, edited by Carey C. Thompson. Austin, TX: University of Texas Press, 1967.

Dewey, John. Intelligence in the Modern World: John Dewey's Philosophy. New York, NY: Modern Library, [1919] 1939.

Forstater, Mathew. "Flexible Full Employment: Structural Implications of Discretionary Public Sector Employment." Journal of Economic Issues 32, 2 (1998): 557-564.

_. "Functional Finance and Full Employment: Lessons from Lerner for Today." Journal of Economic Issues 33, 2 (1999): 475-482.

—_. "Full Employment Policies Must Consider Effective Demand and Structural and Technological Change: A Prime Point of Pasinetti's Political Economy." In A Post Keynesian Perspective on $21^{\text {st }}$ Century Economic Problems edited by Paul Davidson. Cheltenham, UK and Northampton, MA: Edward Elgar, 2002.

Foster, J. Fagg. "The Reality of the Present and the Challenge of the Future." Journal of Economic Issues 15, 4 (1981a): 963-968.

—. "Syllabus for Problems of Modern Society: The Theory of Institutional Adjustment." Journal of Economic Issues 15, 4 (1981b): 929-935.

Fullwiler, Scott T. "Macroeconomic Stabilization through an Employer of Last Resort," Center for Full Employment and Price Stability. Working Paper \# 44 (August 2005). Available at: http:// www.cfeps.org/pubs/.

Gordon, Wendell C. Institutional Economics. Austin, TX: University of Texas Press, 1980.

_ _. "Job Assurance: The Job Guarantee Revisited." Journal of Economic Issues 21, 3 (1997): 817-825.

Kaboub, Fadhel. A Roadmap to Full Employment and Price Stability: The Case of Tunisia. Ph.D. Dissertation, University of Missouri - Kansas City, 2006. 
Kadmos, George Anthony, and O’Hara, Phillip Anthony. "The Taxes-Drive-Money and Employer of Last Resort Approach to Government Policy.” Journal of Economic and Social Policy 5 (Summer 2000): 1 22.

Kitson, M., J. Michie, and H. Sutherland. "A Price Well Worth Paying? The Benefits of a Full-Employment Strategy.” In Employment and Economic Performance: Jobs, Inflation and Growth, edited by Jonathan Michie and John Grieve Smith. Oxford: Oxford University Press, 1997.

Majewski, Raymond. "Simulating an Employer of Last Resort Program.” In Growth, Distribution, and Effective Demand: Alternatives to Economic Orthodoxy, Essays in Honor of Edward J. Nell, edited by George Argyrous, Mathew Forstater, and Gary Mongiovi. Armonk, NY: M.E. Sharpe Inc., 2004.

Minsky, Hyman P. Stabilizing an Unstable Economy. New Haven, CT: Yale University Press, 1986.

Mitchell, William F. "The Job Guarantee and Inflation Control." In Achieving Full Employment, edited by Ellen Carlson and William F. Mitchell. Sydney, Australia: University of New South Wales Press, 2001.

Mitchell, William F., and Martin J. Watts. “The Path to Full Employment.” Australian Economic Review 30 (December 1997): 433-435.

—_. "Restoring Full Employment: The Job Guarantee." In The Urgency of Full Employment, edited by Ellen Carlson and William F. Mitchell. Sydney, Australia: University of New South Wales Press, 2002.

Sawyer, Malcolm. "Employer of Last Resort: Could It Deliver Full Employment and Price Stability?" Journal of Economic Issues 37, 4 (2003): 881-907.

—_. "Employer of Last Resort: A Reply to My Critics." Journal of Economic Issues 39, 1 (2005): 256-264.

Swaney, James. "Elements of Neoinstitutional Environmental Economics.” In Evolutionary Economics: Institutional Theory and Policy, Vol. II edited by Marc Tool. Armonk, NY and London, UK: M. E. Sharpe, 1988.

Tool, Mark. "The Theory of Instrumental Value: Extensions, Clarifications." In Institutional Economics: Theory, Methodology, and Policy, edited by Marc Tool. Boston, Dordrecht, and London: Kluwer Academic Publishers, 1993.

Wray, L. Randall. Understanding Modern Money: The Key to Full Employment and Price Stability. Northampton, MA: Edward Elgar Publishing, 1998a.

"Zero Unemployment and Stable Prices." Journal of Economic Issues 32, 2 (1998b): 539-546.

"Public Service Employment-Assured Jobs Program: Further Considerations." Journal of Economic Issues 33, 2 (1999): 483-490. 